\title{
PENINGKATAN MOTIVASI BELAJAR MELALUI STRATEGI PERMAINAN KARTU DOMINO PADA MATA PELAJARAN PKN DI SMP
}

\author{
Pajarudin \\ Sekolah Menengah Pertama Negeri 1 Singkawang \\ Jalan Merpati Melayu, Singkawang Barat Kota Singkawang, Kalimantan Barat 79111 \\ e-mail: pajarudinspdmsi@gmail.com
}

\begin{abstract}
Abstrak
Penelitian bertujuan untuk meningkatan motivasi belajar PKn melalui permainan kartu domino pada siswa kelas VIII A SMP Negeri 1 Singkawang. Jenis penelitian adalah penelitian tindakan kelas. Tahap pelaksanaannya dibagi dalam tiga siklus (siklus 1 dengan dua kali pertemuan, siklus 2 dengan 3 kali pertemuan, dan siklus 3 dengan tiga kali pertemuan). Alat pengumpul data yang digunakan ialah angket dan observasi. Hasil penelitian menunjukkan pembelajaran berlangsung lebih menyenangkan, siswa lebih antusias dalam bermain, terciptanya tutor sebaya, siswa termotivasi belajar PKn, siswa semakin mengerti dengan permainan kartu bukan semata-mata untuk judi, sehingga strategi pembelajaran dengan permainan kartu domino dapat meningkatkan motivasi belajar siswa.
\end{abstract}

Kata Kunci: motivasi belajar, strategi, permainan kartu domino.

\begin{abstract}
This study aimed to improve PKn learning motivation through domino card games at the eighth grade students of SMPN 1 Singkawang. This research was classroom action research; it was conducted in three cycles. In cycle 1 consisted of two meetings, in cycle 2 consisted of three meetings and so was the cycle 3. To collect the data of the research, the researcher usedquestionnaire and observation. The results of the study showed that learning takes place more pleasantly, students are more enthusiastic in playing, invented a peer tutor, students are motivated to learn Civics, students understand more about card games not merely for gambling, in addition, learning strategies with domino cards can increase students' learning motivation.
\end{abstract}

Keywords: learning motivation, strategy, domino card games.

\section{PENDAHULUAN}

Motivasi adalah dorongan yang ada dalam diri seseorang yang merupakan respon dari suatu aksi. Motivasi muncul dalam diri seseorang karena adanya rangsangan, diantaranya adalah tujuan atau cita-cita. Menurut Sardiman (2016), motivasi adalah perubahan dalam diri seseorang yang ditandai dengan adanya feeling dan didahului dengan tanggapan-tanggapan terhadap adanya tujuan. 
Menurut Frued (2007), motif merupakan energi dasar yang terdapat dalam diri seseorang, tiap tingkah laku manusia didorong oleh suatu energi dasar yaitu instink. Sedangkan motivasi belajar menurut Ali (2008), keseluruhan daya penggerak psikis dalam diri siswa yang menimbulkan kegiatan belajar, menjamin kelangsungan belajar demi mencapai suatu tujuan. Selanjutnya menurut Diane (2010), motivation is an energy change which is characterized by affective arousel and anticipatory goal reactions.

Berdasarkan beberapa pendapat tersebut, dapat disimpulkan bahwa motivasi belajar adalah energi dasar sebagai keseluruhan daya penggerak dalam diri siswa yang bersifat psikis yang memberi dorongan atau rangsangan pada afeksi seseorang untuk melakukan atau tidak melakukan sesuatu (kegiatan belajar) yang efektif dalam mencapai tujuan. Dapat juga dikatakan sebagai rangkaian usaha untuk menyediakan kondisi-kondisi tertentu sehingga seseorang mau dan ingin melakukan sesuatu. Secara umum faktor yang memengaruhi motivasi belajar dapat dibedakan menjadi dua macam, yaitu internal dan eksternal. Hal tesebut sesuai dengan pendapat Uli (2011), motivasi belajar dapat timbul dari dalam diri individu dan dapat pula timbul akibat pengaruh dari luar dirinya. Makin tepat motivasi yang diberikan akan makin berhasil pula pelajaran. Jadi motivasi akan senantiasa menentukan intensitas usaha belajar bagi para siswa. Untuk meningkatkan motivasi belajar perlu dirancang sebuah strategi pembelajaran.

Strategi merupakan komponen penting dalam perencanaan, pelaksanaan, dan evaluasi pembelajaran. Banyak strategi yang dapat digunakan untuk kegiatan pembelajaran, namun tidak semua cocok untuk menyampaikan materi pembelajaran dan untuk semua siswa. Strategi tersebut harus dipilih dengan cermat agar dapat digunakan secara optimal dalam kegiatan pembelajaran. Dalam rangka pengembangan pembelajaran, salah satu tugas guru adalah memilih strategi pembelajaran yang digunakan untuk membantu siswa mencapai kompetensi yang diinginkan. Strategi lebih luas pengertiannya dari metode pembelajaran, mengandung makna sebagai alternatif kegiatan dan pendekatan yang dapat dipilih untuk mencapai tujuan pembelajaran. Termasuk dalam strategi pembelajaran adalah materi dan paket pembelajaran. Menurut Dick dan Carey 
(2008), strategi pembelajaran diartikan sebagai semua komponen materi, paket pengajaran, dan prosedur yang digunakan untuk membantu siswa dalam mencapai tujuan pembelajaran tertentu. Adapun salah satu strategi pembelajaran untuk meningkatkan motivasi belajar yaitu permainan kartu domino.

Permainan kartu domino dimainkan layaknya orang bermain "Gaplek" yang dirancang dengan aturan yang dibuat oleh kelompok siswa dalam permainan tersebut. Satu kelompok terdiri dari empat orang. Pemenangnya akan memperebutkan satu kartu soal yang akan dijawab oleh kelompok siswa yang kalah dalam kelompok tersebut. Sebelum permainan dimulai, terlebih dahulu disusun skema permainan dan bagi pemenangnya akan diberi kesempatan untuk memilih satu kartu soal dan mendapatkan nilai, selanjutnya menugaskan kepada kelompok yang kalah untuk menjawab soal tersebut dan mendiskusikan jawaban soal tersebut di kelompoknya. Permainan kartu domino diharapkan mampu memberikan motivasi belajar siswa dan bermanfaat bagi siswa terutama dalam meningkatkan gairah belajar PKn, selanjutnya bagi guru dapat menambah wawasan dalam mengaplikasikan strategi baru guna membantu siswa belajar PKn. Oleh karenanya, pengembangan strategi pembelajaran dengan model permainan kartu domino merupakan hal yang patut menjadi perhatian peneliti dalam upaya peningkatan kualitas pendidikan, khususnya di daerah yang miskin dengan berbagai sarana prasarana penunjang dan umumnya untuk mewujudkan kualitas pendidikan nasional.

Proses pembelajaran yang bermutu, ditandai oleh terciptanya suasana kelas yang kondusif dan produktif untuk memberikan pengalaman belajar kepada siswa melalui pelibatannya secara proaktif dan integratif serta tercapainya seluruh ranah dalam tujuan pembelajaran (kognitif, afektif, dan psikomotorik). Penelitian tindakan kelas diawali dengan munculnya berbagai permasalahan pembelajaran pada mata pelajaran PKn, diantaranya siswa tidak gairah, kurang persiapan mengikuti pelajaran, kurang disiplin, dan nilai menurun. Hal tersebut terjadi sebagai gajala menurunnya motivasi belajar siswa terhadap mata pelajaran PKn. Rendahnya motivasi belajar siswa terhadap pelajaran PKn, secara psikologis dikarenakan PKn adalah kelompok mata pelajaran yang non-UN (Ujian 
Nasional), sehingga PKn mengalami krisis perhatian, baik dari siswa maupun orang tua, perhatiannya lebih terfokus pada mata pelajaran Matematika, Bahasa Indonesia, dan Bahasa Inggris yang lebih menentukan nasib siswa. Meskipun nilai PKn kenyataannya rendah, tetapi para siswa tidak butuh pelajaran tersebut untuk ditingkatkan. Terlabih lagi, kurang variasinya strategi pembelajaran yang digunakan guru sehingga pembelajaran monoton menggunakan metode ceramah. Karenanya, penelitian diarahkan kepada guru PKn agar mau bekerja keras untuk melakukan inovasi pembelajaran baik dengan strategi, media, teknik, sarana yang variatif sehingga mampu meningkatkan motivasi belajar siswa. Salah satu pendekatan yang diyakini mampu mendorong siswa belajar aktif dan termotivasi, yaitu suatu konsep belajar yang membantu guru mengaitkan antara materi yang diajarkan dengan situasi dunia nyata siswa dan mendorong siswa membuat hubungan antara pengetahuan yang dimilikinya dengan penerapannya dalam kehidupan mereka sebagai anggota keluarga dan masyarakat (Kemendikbud, 2013).

Kartu domino yaitu permainan gaplek yang biasa dimainkan orang dewasa secara berkelompok dengan berpasang-pasangan. Sementara bermain kartu domino diidentikkan dengan perjudian. Peneliti ingin mengubah pola permainan yang asumsinya judi dijadikan sebagai strategi kegiatan belajar mengajar, serta permainan mempunyai aktivitas yang mempunyai tujuan dan elemen kesenangan. Oleh karenanya, diharapkan dengan permainan kartu domino mampu mingkatkan semangat siswa untuk belajar sehingga motivasi belajarnya menjadi lebih baik. Hasil penelitian Eni (2017), menunjukkan penerapan pembelajaran Matematika dengan menggunakan media kartu domino matematika mampu meningkatkan motivasi dan hasil prestasi belajar siswa kelas IXA SMP Negeri Unggulan Sindang Kabupaten Indramayu.

Hasil penelitian Djamilah (2015), menjelaskan bahwa penggunaan media pembelajaran kartu domino dapat meningkatkan nilai mata pelajaran Kimia. Hasil penelitian Abdur (2017), memperlihatkan bahwa latihan soal dengan menggunakan media pembelajaran kartu domino pada soal-soal Matematika dapat meningkatkan motivasi belajar santri di Masjid Al Muhajirin. Hasil penelitian 
Faizal dan Mahardia (2017), memperlihatkan bahwa kartu domica berbasis open ended hasil uji coba berkualitas baik karena telah memenuhi aspek kevalidan, kepraktisan, dan keefektivan untuk melatihkan kreativitas siswa dalam aspek kefasihan, fleksibiltas, elaborasi, dan kebaharuan.

\section{METODE}

Metode yang digunakan dalam penelitian adalah deskriptif, dengan jenis penelitian yaitu penelitian tindakan kelas (PTK). PTK dapat diartikan sebagai proses pengakajian masalah pembelajaran di dalam kelas melalui refleksi diri dalam upaya pemecahan masalah dengan cara melakukan berbagai tindakan yang terencana dalam situasi nyata serta menganalisis setiap pengaruh dari perlakuan PTK, yang bertujuan melakukan perubahan ke arah yang lebih baik sebagai upaya pemecahan masalah pembelajaran yang sedang dihadapi di dalam kelas dengan tahapan perencanaan, pelaksanaan, pengamatan, dan refleksi. Tahap pelaksanaannya dibagi dalam tiga siklus masing-masing waktu pertemuan 45 menit (siklus 1 dengan dua kali pertemuan, siklus 2 dengan 3 kali pertemuan, dan siklus 3 dengan tiga kali pertemuan), melalui pendekatan kualitatif yang pengolahan data hasil penelitian dilakukan secara verbal yaitu dalam bentuk kumpulan rekaman pengamatan dan observasi tindakan selama melakukan kegiatan proses belajar mengajar di kelas.

Teknik pengumpulan data yang digunakan dalam penelitan adalah teknik observasi langsung, teknik komunikasi tidak langsung, dan studi dokumenter. Alat pengumpul data yang digunakan ialah angket, pedoman observasi, dan dokumentasi. Data diolah secara deskriptif berdasarkan temuan di lapangan dalam beberapa deskriptor (gejala yang muncul) melalui hasil angket dan observasi, selanjutnya diambil kesimpulan untuk mengetahui tingkat kemajuan atau kemunduran motivasi belajar siswa. Subjek penelitian adalah siswa kelas VIII A dan Guru Pendidikan Kewarganegaraan SMP Negeri 1 Singkawang. 


\section{HASIL DAN PEMBAHASAN}

\section{Gambaran Motivasi Belajar Siswa}

Hasil penyebaran angket motivasi belajar siswa kelas VIII A SMP Negeri 1 Singkawang dapat dilihat pada tabel berikut.

\section{Tabel 1 Gambaran Umum Motivasi Belajar Siswa pada Mata Pelajaran PKn}

\begin{tabular}{clcc}
\hline No & \multicolumn{1}{c}{ Aspek } & $\begin{array}{c}\text { Persentase } \\
(\%)\end{array}$ & Kategori \\
\hline 1 & $\begin{array}{l}\text { Keseriusan siswa dalam mengikuti } \\
\text { pelajaran }\end{array}$ & 50 & Cukup \\
2 & $\begin{array}{l}\text { Persiapan siswa dalam mengikuti } \\
\text { pelajaran }\end{array}$ & 45 & Cukup \\
3 & $\begin{array}{l}\text { Aktif mendengar penjelasan guru } \\
4\end{array}$ & 40 & Cukup \\
& $\begin{array}{l}\text { Aktivitas siswa dalam mengerjakan tugas } \\
\text { di kelompok }\end{array}$ & 32 & Kurang \\
& $\begin{array}{l}\text { Keterlibatan siswa dalam diskusi } \\
\text { kelompok }\end{array}$ & 33 & Kurang \\
6 & $\begin{array}{l}\text { Kedisiplinan siswa dalam mengikuti } \\
\text { pelajaran }\end{array}$ & 45 & Cukup \\
7 & $\begin{array}{l}\text { Aktivitas siswa dalam mengikuti } \\
\text { pelajaran }\end{array}$ & 40 & Cukup \\
8 & $\begin{array}{l}\text { Ada usaha untuk mendapatkan hasil } \\
\text { yang terbaik } \\
9\end{array}$ & $\begin{array}{l}\text { keaktifan memberi tanggapan dalam } \\
\text { kelompok }\end{array}$ & Cukup \\
10 & $\begin{array}{l}\text { Keberanian siswa untuk bertanya dan } \\
\text { tampil } \\
\text { Aktif membantu teman yang kesulitan } \\
\text { mengerjakan soal }\end{array}$ & 50 & Cukup \\
\hline
\end{tabular}

\section{Siklus 1}

\section{Perencanaan}

Untuk mendukung terlaksanannya penelitian tindakan kelas, dipersiapkan segala sesuatu yang diperlukan, seperti perangkat pembelajaran (RPP), lembar kerja siswa (LKS), serta instrumen pendukung lainnya seperti lembar tes, dan lembar observasi. 


\section{Pelaksanaan}

Siklus 1 dilaksanakan dalam dua kali pertemuan, yaitu diawali dengan tes awal (t-O), selanjutnya dilaksanakan kegiatan pembelajaran menggunakan strategi permainan domino tiap kelompok diberi masalah yang berbeda untuk dibahas yang berhubungan dengan materi peraturan perundang-undangan, selanjutnya masing-masing kelompok mempresentasikan ke depan dengan ditanggapi oleh kelompok lain secara bebas.

\section{Pengamatan}

Selama kegiatan berlangsung dalam waktu 45 menit, kegiatan pembelajaran diobservasi menggunakan lembar observasi dan mencatat segala sesuatu yang terjadi selama pelajaran berlangsung dengan 20 siswa. Temuan-temuan yang dicatat dalam lembar catatan lapangan. Hasilnya terlihat pada tabel berikut.

Tabel 2 Persentase Pekembangan Motivasi Belajar Siswa Siklus 1

\begin{tabular}{llcl}
\hline No & \multicolumn{1}{c}{ Aspek } & $\begin{array}{c}\text { Persentase } \\
(\%)\end{array}$ & Kategori \\
\hline 1 & Keseriusan siswa dalam mengikuti pelajaran & 52 & Cukup \\
2 & Persiapan siswa dalam mengikuti pelajaran & 47 & Cukup \\
3 & Aktif mendengar penjelasan guru & 45 & Cukup \\
4 & Aktivitas siswa dalam mengerjakan tugas di & 34 & Cukup \\
& kelompok & & \\
5 & Keterlibatan siswa dalam diskusi kelompok & 35 & Cukup \\
6 & Kedisiplinan siswa dalam mengikuti & 50 & Cukup \\
& pelajaran & & \\
7 & Aktivitas siswa dalam mengikuti pelajaran & 52 & Cukup \\
8 & $\begin{array}{l}\text { Ada usaha untuk mendapatkan hasil yang } \\
\text { terbaik }\end{array}$ & 65 & Cukup \\
9 & $\begin{array}{l}\text { Keaktifan memberi tanggapan dalam } \\
\text { kelompok }\end{array}$ & 60 & Cukup \\
10 & Keberanian siswa untuk bertanya dan tampil & 55 & Cukup \\
11 & Aktif membantu teman yang kesulitan & 50 & Cukup \\
& mengerjakan soal & & \\
\hline
\end{tabular}

Untuk mengukur kemampuan siswa dalam penguasaan materi pelajaran setelah dua kali pertemuan dilakukan pos tes (t-1), dengan hasil: siswa yang nilainya meningkat berjumlah 20 orang, setelah dibandingkan dengan tes awal (t- 
O). Rata-rata kenaikan nilai kemampuan siswa mengikuti pembelajaran adalah $2,5 \%$ dari $\mathrm{t}-\mathrm{O}=50$ menjadi $\mathrm{t}-1=52$.

\section{Refleksi}

Selama siklus pertama beberapa hal yang menjadi catatan adalah keseriusan siswa dalam mengikuti pelajaran kurang, kurang semangat, kedisiplinan siswa yang kurang, kurangnya kebersamaan dan kekeluargaan, kurang keseriusan siswa untuk tampil. Untuk mengurangi masalah tersebut, maka pada siklus kedua dilakukan tindakan yaitu diadakan penilaian proses terhadap siswa secara langsung oleh peneliti dan kegiatan pembelajaran dilakukan dengan permainan kartu domino agar lebih membantu siswa untuk belajar sambil bermain.

\section{Siklus 2}

\section{Perencanaan}

Untuk mendukung terlaksanannya penelitian tindakan kelas pada siklus 2, dipersiapkan segala sesuatu yang diperlukan, seperti: RPP, LK), serta instrumen pendukung lainnya seperti lembar tes, lembar observasi, skema permainan, kartu domino.

\section{Pelaksanaan}

Siklus 2 dilakukan dalam tiga kali pertemuan, kegiatan belajar dilakukan dengan menggunakan metode diskusi melalui permainan kartu domino. Kegiatan diawali dengan penjelasan cara bermain serta penarikan undian dan penyusunan skema permainan. Selanjutnya pasangan pemenang akan memperoleh satu kartu soal (LKS) yang akan diserahkan kepada pasangan yang kalah untuk menjawab dan selanjutnya mereka diskusikan dalam kelompok tersebut. Selesai diskusi pasangan pemenang memberikan nilai kepada pasangan yang kalah. Permainan dilanjutkan sesuai skema permainan dengan cara yang sama sampai skema permainan selesai. Kegiatan tersebut memerlukan waktu 3 kali pertemuan (3 x 45 menit).

\section{Pengamatan}

Pada tahap pengamatan terlihat peningkatan motivasi belajar siswa cukup signifikan, dengan hasil observasi kolaborator seperti pada tabel berikut. 
Tabel 3 Persentase Pekembangan Motivasi Belajar Siswa Siklus II

\begin{tabular}{|c|c|c|c|}
\hline No & Aspek & $\begin{array}{l}\text { Persen- } \\
\text { tase }(\%)\end{array}$ & Kategori \\
\hline 1 & Keseriusan siswa dalam mengikuti pelajaran & 57 & Cukup \\
\hline 2 & Persiapan siswa dalam mengikuti pelajaran & 50 & Cukup \\
\hline 3 & Aktif mendengar penjelasan guru & 50 & Cukup \\
\hline 4 & $\begin{array}{l}\text { Aktivitas siswa dalam mengerjakan tugas di } \\
\text { kelompok }\end{array}$ & 45 & Cukup \\
\hline 5 & Keterlibatan siswa dalam diskusi kelompok & 46 & Cukup \\
\hline 6 & $\begin{array}{l}\text { Kedisiplinan siswa dalam mengikuti } \\
\text { pelajaran }\end{array}$ & 55 & Cukup \\
\hline 7 & Aktivitas siswa dalam mengikuti pelajaran & 57 & Cukup \\
\hline 8 & $\begin{array}{l}\text { Ada usaha untuk mendapatkan hasil yang } \\
\text { terbaik }\end{array}$ & 66 & Cukup \\
\hline 9 & $\begin{array}{l}\text { keaktifan memberi tanggapan dalam } \\
\text { kelompok }\end{array}$ & 66 & Cukup \\
\hline 10 & Keberanian siswa untuk bertanya dan tampil & 60 & Cukup \\
\hline 11 & $\begin{array}{l}\text { Aktif membantu teman yang kesulitan } \\
\text { mengerjakan soal }\end{array}$ & 55 & Cukup \\
\hline
\end{tabular}

\section{Refleksi}

Selama siklus 2, beberapa hal yang menjadi catatan kolaborator yang dianggap baik adalah keseriusan siswa dalam mengikuti pelajaran, persiapan siswa dalam mengikuti pelajaran, keaktifan siswa mendengar penjelasan guru, aktivitas siswa dalam mengerjakan tugas di kelompok, kedisiplinan siswa dalam mengikuti pelajaran, aktivitas siswa dalam mengikuti pelajaran, keaktifan memberi tanggapan dalam kelompok, dan keberanian siswa untuk bertanya dan tampil. Yang perlu mendapat perhatian dari peneliti adalah kurangnya keterlibatan siswa dalam diskusi kelompok, belum ada usaha siswa untuk mendapatkan hasil yang terbaik, serta masih kurang aktif membantu teman yang kesulitan, karena siswa termotivasi untuk saling berkompetisi antara satu pasangan dengan pasangan lainnya. Oleh karenanya, untuk siklus yang ketiga peneliti perlu memperhatikan kemauan siswa membantu teman yang kesulitan mengerjakan soal dengan cara meningkatkan pengamatan dan pemberian reward (penghargaan) kepada pasangan pemenang baik dengan hadiah maupun dengan nilai. 


\section{Siklus 3}

\section{Perencanaan}

Untuk mendukung terlaksanannya penelitian tindakan kelas pada siklus 3, dipersiapkan segala sesuatu yang diperlukan, seperti RPP, LKS, serta instrumen pendukung lainnya seperti lembar tes, lembar observasi, skema permainan, kartu domino, dan dengan aturan permainan secara lebih ketat.

\section{Pelaksanaan}

Siklus ketiga dilakukan dalam tiga kali pertemuan, kegiatan belajar dilakukan dengan menggunakan strategi permainan kartu domino. Bertolak dari hasil refleksi pada siklus 2, guru melakukan KBM dengan permainan kartu domino secara lebih ketat, diantaranya mengelompokan siswa berdasarkan tingkat kecakapan yang relatif sama, baik dari sisi kemampuannya, keterampilan maupun kenakalannya. Selanjutnya dalam siklus 2 , jumlah game adalah 100 , sedangkan untuk siklus 3 jumlah permainan mencapai nilai 50, agar permainan lebih cepat dan siswa terfokus untuk menjawab soal-soal serta mendiskusikannya dikelompoknya masing-masing. Kegiatan tersebut memerlukan waktu 3 kali pertemuan ( 3 x 45 menit).

\section{Pengamatan}

Pada tahap pengamatan, terlihat pertumbuhan motivasi belajar siswa baik, dengan hasil observasi seperti pada tabel berikut.

Tabel 4 Persentase Peningkatan Pekembangan Motivasi Belajar Siswa

\begin{tabular}{clcccc}
\hline No & \multicolumn{1}{c}{ Aspek } & Sebelum & $\begin{array}{c}\text { Siklus } \\
\mathbf{1}\end{array}$ & $\begin{array}{c}\text { Siklus } \\
\mathbf{2}\end{array}$ & $\begin{array}{c}\text { Siklus } \\
\mathbf{3}\end{array}$ \\
\hline 1 & $\begin{array}{l}\text { Keseriusan siswa dalam } \\
\text { mengikuti pelajaran } \\
2\end{array}$ & 50 & 52 & 57 & 67 \\
$\begin{array}{l}\text { Persiapan siswa dalam } \\
\text { mengikuti pelajaran } \\
3\end{array}$ & 45 & 47 & 50 & 60 \\
$\begin{array}{l}\text { Aktif mendengar penjelasan } \\
\text { guru }\end{array}$ & 40 & 45 & 50 & 55 \\
$\begin{array}{l}\text { Aktivitas siswa dalam } \\
\text { mengerjakan tugas di }\end{array}$ & 32 & 34 & 45 & 55 \\
kelompok & $\begin{array}{l}\text { Keterlibatan siswa dalam } \\
\text { diskusi kelompok }\end{array}$ & 33 & 35 & 46 & 56
\end{tabular}




\begin{tabular}{|c|c|c|c|c|c|}
\hline No & Aspek & Sebelum & $\begin{array}{c}\text { Siklus } \\
1\end{array}$ & $\begin{array}{c}\text { Siklus } \\
2\end{array}$ & $\begin{array}{l}\text { Siklus } \\
\quad 3\end{array}$ \\
\hline 6 & $\begin{array}{l}\text { Kedisiplinan siswa dalam } \\
\text { mengikuti pelajaran }\end{array}$ & 45 & 50 & 55 & 60 \\
\hline 7 & $\begin{array}{l}\text { Aktivitas siswa dalam } \\
\text { mengikuti pelajaran }\end{array}$ & 40 & 52 & 57 & 67 \\
\hline 8 & $\begin{array}{l}\text { Ada usaha untuk } \\
\text { mendapatkan hasil yang } \\
\text { terbaik }\end{array}$ & 62 & 65 & 66 & 70 \\
\hline 9 & $\begin{array}{l}\text { keaktifan memberi } \\
\text { tanggapan dalam kelompok }\end{array}$ & 50 & 60 & 66 & 70 \\
\hline 10 & $\begin{array}{l}\text { Keberanian siswa untuk } \\
\text { bertanya dan tampil }\end{array}$ & 50 & 55 & 60 & 70 \\
\hline 11 & $\begin{array}{l}\text { Aktif membantu teman yang } \\
\text { kesulitan mengerjakan soal }\end{array}$ & 41 & 50 & 55 & 60 \\
\hline
\end{tabular}

Secara keseluruhan, motivasi belajar siswa pada setiap tahap tindakan mengalami peningkatan. Keseriusan siswa dalam mengikuti pelajaran, persiapan siswa dalam mengikuti pelajaran, aktif mendengar penjelasan guru, aktivitas siswa dalam mengerjakan tugas di kelompok, keterlibatan siswa dalam diskusi kelompok, kedisiplinan siswa dalam mengikuti pelajaran, keberanian siswa untuk bertanya dan tampil, aktif membantu teman yang kesulitan mengerjakan soal. Hal tersebut menunjukkan bahwa pemberian strategi permainan kartu domino dapat meningkatkan motivasi belajar siswa kelas VIII A. Sejalan dengan hasil penelitian Abdur (2017), latihan soal dengan menggunakan media pembelajaran kartu domino pada soal-soal Matematika dapat meningkatkan motivasi belajar santri di Masjid Al Muhajirin. Hal tersebut terlihat dari hasil ujian yang mengalami peningkatan $85 \%$ dan $100 \%$ santri menyatakan minat (tertarik) dengan latihan soal dengan menggunakan media pembelajaran kartu domino. Hasil penelitian Firman, Edy, dan Cholis (2018), menunjukkan bahwa dengan menggunakan media permainan kartu domino, keterampilan berhitung siswa dalam mengonversi pecahan ke desimal dan desimal ke pecahan dapat meningkat. Siswa terlatih dan antusias untuk menghubungkan tiap-tiap kartu domino dengan perasaan senang dan kompetitif. Siswa dengan semangat berhitung konversi pecahan-desimal dan dengan teliti mengoreksi hasil jawaban dari temannya. Siswa yang kemampuan 
hitungnya tinggi akan membantu siswa yang berkemampuan rendah dalam berhitung.

Motivasi belajar sebagai hasil penelitian dalam strategi pembelajaran menggunakan permainan kartu domino mengindikasikan bahwa siswa kelas VIII A mempunyai motivasi dalam belajar. Motivasi yang ada pada diri siswa sangat penting dalam kegiatan belajar. Ada tidaknya motivasi seseorang untuk belajar sangat berpengaruh dalam proses aktivitas belajar. Seperti dikemukakan oleh Sadiman (2012), motivasi memliki ciri-ciri: (1) Tekun menghadapi tugas (dapat bekerja terus menerus dalam waktu yang lama, tidak pernah berhenti sebelum selesai); (2) Ulet menghadapi kesulitan. Tidak memerlukan borongan dari luar untuk berprestasi sebaik mungkin; (3) Mewujudkan minat terhadap bermacam macam masalah untuk orang dewasa; (4) Lebih senang bekerja mandiri; (5) Cepat bosan pada tugas tugas yang rutin (kurang kreatif); (6) Dapat mempertahankan pendapatnya; (7) Tidak mudah melepaskan hal yang diyakini; dan (8) Senang mencari dan mengucapkan masalah soal.

\section{SIMPULAN}

Berdasarkan hasil penelitian dapat disimpulkan bahwa: (1) Motivasi belajar siswa kelas VIII A SMP Negeri 1 Singkawang tergolong cukup; (2) Pelaksanaan strategi kartu domino pada mata pelajaran PKn telah terlaksana dengan baik dan tepat diterapkan dalam proses pembelajaran; dan (3) Terdapat peningkatan motivasi belajar siswa setelah menggunakan strategi permainan kartu domino dari 3 siklus yang telah dilaksanakan. Sarankan kepada siswa agar selalu berusaha meningkatkan motivasi belajar untuk menunjang pencapaian hasil belajar yang optimal, khususnya siswa yang tergolong katagori kurang. Sehubungan dengan pentingnya motivasi belajar, sebaiknya penanganan oleh guru mata pelajaran, dengan memberikan strategi pembelajaran yang kreatif dan inovatif.

\section{DAFTAR PUSTAKA}

Abdur. 2017. Penggunaan Media Pembelajaran Kartu Domino untuk Memotivasi Santri di Masjid Al Muhajirin Banyuajuh dalam Mengerjakan Soal Matematika. Jurnal Program Studi Pendidikan Matematika, 3(2): 44-54. Ali. 2008. Belajar dan Pembelajaran, Jakarta: Pustaka Jaya. 
Diane. 2010. Teaching and Learning Philosophical, Psychological, Curricular Applications, New York: Macmillan Publishing Co.,Inc.

Dick \& Carey. 2008. The Systematic Design Of Instruction, Illionois: Foresman Co.

Djamilah. 2015. Kartu Domino sebagai Media Pembelajaran pada Mata Pelajaran Kimia di Sekolah Menengah Atas (SMA). Jurnal Lingkar Widyaiswara, 2(1): 21-37.

Eni. 2017. Upaya Meningkatkan Motivasi dan Hasil Belajar Siswa Menggunakan Media Pembelajaran Kartu Domino Matematika pada Materi Pangkat Tak Sebenarnya dan Bentuk Akar Kelas IX SMP Negeri Unggaran Sindang Kabupaten Indramayu. Jurnal Nasional Pendidikan Matematika, 6(1): 6681.

Faizal \& Mahardika. 2017. Pengembangan Domino Pecahan Berbasis Open Ended untuk Meningkatkan Kemampuan Berpikir Kreatif Siswa. Jurnal Program Studi Pendidikan Matematika, 6(2): 30-45.

Firman, Edy, \& Cholis. 2018. Media Permainan Kartu Domino untuk Meningkatkan Keterampilan Berhitung Konversi Pecahan Desimal Siswa Kelas IV. Jurnal Pendidikan: Teori, Penelitian, dan Pengembangan, 3(9): 1190-1199.

Frued. 2007. Psikologi Pendidikan dengan Pendekatan Baru, Bandung: Remaja Rosdakarya.

Kemendikbud. 2013. Pedoman Pembuatan Laporan Hasil Belajar, Jakarta: Balai Pustaka.

Sadiman. 2012. Media pendidikan pengertian, pengembangan dan pemanfaatannya. Jakarta: Pustekkom Dikbud dan PT. Raja Grafindo Persada.

Sardiman. 2016. Interaksi dan Motivasi Belajar Mengajar, Jakarta: Raja Grafindo Husada.

Uli. 2011. Menjadi Guru Profesional, Bandung: Remaja Rosdakarya. 